\title{
MILK QUALITY AND DAIRY PRODUCT DEVELOPMENT OF A NORMANDE COW HERD IN THE REGION OF ÑUBLE, CHILE
}

\author{
Christian Guajardo ${ }^{1 *}$, Valeria Velasco ${ }^{1}$, Rita Astudillo ${ }^{2 *}$, Carlos Cáceres ${ }^{3}$, Catalina Cea $^{3}$, Jorge \\ Campos $^{1}$, Margarita Ocampo ${ }^{3}$, Luis Seminario ${ }^{3}$
}

${ }^{1}$ University of Concepción, Faculty of Agronomy, Department of Livestock Management, Avenue Vicente Méndez 595, Chillán, Chile.chguajar@udec.cl, vvelasco@udec.cl, jcamposp@udec.cl,

${ }^{2}$ University of Concepción, Faculty of Veterinary, Department of Animal Science, Avenue Vicente Méndez 595, Chillán, Chile. riastudi@udec.cl.

${ }^{3}$ University of Concepción, Faculty of Agricultural Engineering, Avenue Vicente Méndez 595, Chillán, Chile.carlosnicolacac@udec.cl, catacea@udec.cl, mocampo@udec.cl, lseminario@udec.cl.

*Corresponding author E-mail: chguajar@udec.cl; riastudi@udec.cl

\begin{abstract}
The dual-purpose Normande breed is characterized for its good adaptation to different production systems. The objective of this study was to determine the milk quality of the first Normande cow herd in the Nuble Region (Chile) compared with that of Holstein Friesian cows, and to develop dairy products. The study was carried out with Normande (N) and Holstein Friesian (HF) cows in the first lactation. Milk quality parameters included titratable acidity, $\mathrm{pH}$, density, fat content, and milk composition; whereas product development included production of Chanco cheese and mozzarella sticks. Chanco cheese was made from $\mathrm{N}$ and HF milk, and yield and composition were determined. Mozzarella sticks were made using $\mathbf{N}$ milk and two different salting processes (pre-salting and brining); color, texture, melting capacity, proximal analysis, and sensory analysis were compared. Fat and protein content of HF cow's milk was $3.35 \%$ and $2.87 \%$, while values for the $\mathrm{N}$ were $3.35 \%$, and $3.16 \%$, respectively. Since there were no differences in fat content between breeds $(P>0.05)$, Chanco cheese yield was similar despite the fact that protein content of $N$ milk was higher $(P \leq 0.05)$. Mozzarella sticks with a salting step at the end (brine at $25 \%$ ) had greater firmness, melting capacity and acceptance $(P \leq 0.05)$. In conclusion, milk from $N$ and HF breeds has different protein and lactose content but similar technological performance for the production of Chanco cheese. It is possible to produce mozzarella cheese sticks using milk from Normande cows and to recommend raising this dual-purpose breed in this Region.
\end{abstract}

Key words: cheese yield, Chanco cheese, mozzarella cheese.

\section{INTRODUCTION}

The annual milk production in Chile reaches 2,650 million liters and generates 130 and 100 thousand tons of cheese, and powdered milk and derivatives, respectively. The consumption of dairy products in the country is close to $150 \mathrm{~L}$ per capita per year, and there is also an important foreign trade (ODEPA, 2019).

Milk quality is mainly determined by milk composition, which is affected by breed, nutrition, time of lactation, and animal health. Among dairy cows breeds, dual-purpose breeds are characterized by a lower milk production potential. However, other zootechnical characteristics, such as capacity to adapt to different production systems, are economically advantageous in systems based on grazing with low supplementation (Delaby et al., 2009). The Normande is an example of a dual-purpose breed with better reproductive performance (Dillon et al., 2003b; Heins et al., 2006a, b; Delaby et al., 
2009) than milk production qualities, producing less milk than Holstein Friesian (Dillon et al., 2003a). In Chile, the Normande breed has been present for approximately 20 years, in a genetic nucleus imported from France, located in the Araucanía Region. It has been recently established in the Nuble Region, so assessments actions are recommended.

Different breeds can be selected for cheese production and developing other dairy products, according to the standards of the target market. It is important to note that high protein and fat content in the milk increases cheese yield (Katz et al., 2016). A traditional aged cheese produced in Chile, called Chanco cheese, is highly preferred among consumers (Aguilera, 2016). It is made from pasteurized cow's milk, with the addition of lactic cultures and a ripening process of about 21 days (INN, 1999). This typical Chilean product does not have a protected designation of origin (Lacoste et al., 2014). Another dairy product that is highly preferred among consumers is mozzarella cheese. This product is traditionally made from buffalo milk but it can also be produced using cow's milk (Hussain et al., 2011). It is characterized by its soft texture, melting and stretching capacity; it is mainly used in pizza making (Zhang et al., 2014).

The objective of this study was to determine milk quality of a Normande cow herd in the Nuble Region as compared with that of Holstein Fresian cows, and to develop dairy products.

\section{MATERIALS AND METHODS}

The study was carried out between January and May 2016 with a herd comprised of 13 Normande and 15 Holstein Friesian cows, all in the first lactation.

Location and facilities. The dairy facility is located in the Animal Research Farm Marcelo Tima Péndola "Fundo El Alazán" (36²6' S; 7206' W), University of Concepción (25 km northwest of Chillán, Chile). It is a mixed production system, which includes a fish-bone milking parlor with a low milk line and six milking units. In summer, dairy cows grazed permanent grasslands of ballica-white clover (Lolilum perennial L. Trifolium repens L.), and were supplemented with red clover hay ( $T$. pratense L.) and a commercial concentrate for high production cows. In winter (June to September), the diet included corn silage, clover hay, wet corn and rape bran.

\section{Milk analysis}

Sampling. Daily milk production (considering two milking) per cow was recorded every 15 days
(The Coburn Company, Waikato MK V meters, Whitewater, Wisconsin, USA). Milk sampling was carried out from the first 15 days post partum, collecting $20 \mathrm{~mL}$ immediately after the first milking in the morning. Milk samples were kept in sterile sealed containers under refrigeration, identified with the registration number of each animal.

Milk samples were analyzed in the Laboratory of Animal Nutrition, University of Concepción, Faculty of Agronomy (Chillán, Chile) and in the Laboratory of the Institute of Agricultural Research (INIA) Carillanca (Temuco, Chile). All analyses were carried out in triplicate.

\section{Milk quality parameters}

Titratable acidity. It was carried out according to the Chilean standard NCh 1738 Of. 98 (INN, 1998). $10 \mathrm{~mL}$ of milk with 3 drops of phenolphthalein were titrated with $\mathrm{NaOH}(0.1 \mathrm{~N})$ until a pale pink color was obtained. The result was expressed as the percentage of lactic acid.

$\mathrm{pH}$. The $\mathrm{pH}$ of milk samples was determined using a $\mathrm{pH}$ meter (Martini Instruments, Mi 150 ATC, Dry Creek, SA, Australia), which was previously calibrated using buffer solutions of pH 4.0 and 7.0, according to the Chilean standard NCh 1671 Of. 79 (INN 1979 a).

Density. The milk sample was homogenized and placed into the test tube. The density was determined using a lactodensimeter (Gamma RTM Dr. J. Ambrus, No. 3,129, Santiago, Chile), by direct reading at a temperature of $20^{\circ} \mathrm{C}$, according to the Chilean standard NCh 1672 Of.79 (INN 1979b).

Fat content. It was determined by the Gerber method (INN, 1979c), using a calibrated butyrometer (Boeco, V1070, Hamburg, Germany), with $10 \mathrm{~mL}$ of $\mathrm{H}_{2} \mathrm{SO}_{4}$ (concentration $90-91 \%$ and density $1.818 \pm 0.003 \mathrm{~g} \mathrm{~mL}^{-1}$ at $\left.20^{\circ} \mathrm{C}\right), 10.77 \mathrm{~mL}$ of the milk and $1 \mathrm{~mL}$ of isoamyl alcohol (2-methyl1-butanol). The butyrometer was stirred and centrifuged at $1100 \pm 100 \mathrm{rpm}$ (diameter $500 \pm$ $25 \mathrm{~mm}$ ) for $4-5 \mathrm{~min}$. Then, the butyrometer was subjected to $65^{\circ} \mathrm{C}$ for $5 \mathrm{~min}$ in a thermoregulated bath. The fat content was directly read via a calibrated butyrometer (Boeco, V1070, Hamburg, Germany).

Milk composition. Fat, protein, total solids and lactose contents as well as acidity, density, $\mathrm{pH}$, urea and somatic cells were determined using MilkoScan ${ }^{\mathrm{TM}}$ equipment (FOSS Denmark) by the Infrared Method, ISO 9622: 2013 Standard (ISO, 2013). All milk analyses were carried out in triplicate.

\section{Chanco cheese development}

Product development was carried out in 
the Laboratory of Dairy Products, University of Concepción, Faculty of Agronomy (Chillán, Chile), while cheese analyses were carried out in the Laboratory of Research, Control and Food Quality Certification (LECYCA), University of Bío Bío (Chillán, Chile).

Chanco cheese production. Milk from Holstein Friesian and Normande breeds was used for making Chanco cheese, according to the methodology proposed by Brito et al. (2003), with slight modifications. Milk was pasteurized $\left(65^{\circ} \mathrm{C}\right.$ for $20 \mathrm{~min}$ ) and cooled (to $35 \pm 2^{\circ} \mathrm{C}$ ). Calcium chloride $\left(0.15 \mathrm{~g} \mathrm{~L} \mathrm{~L}^{-1}\right)$, selected cultures $\mathrm{CHN}$ 22 (CHR Hansen, $0.02 \mathrm{~g} \mathrm{~L}^{-1}$ ) and liquid rennet (Dilaco Ltda., CHYMAX, Santiago, Chile) (0.2 $\mathrm{mL} \mathrm{L}^{-1}$ ) were added. The incubation was carried out at $37 \pm 2^{\circ} \mathrm{C}$ for $40 \mathrm{~min}$ in order to achieve the precipitation of proteins and separation of whey. Salt was added $\left(3.4 \mathrm{~g} \mathrm{~L}^{-1}\right.$ dissolved in $10 \mathrm{~mL}$ of whey) and the curd was placed into $500 \mathrm{~g}$ molds, and pressed using a compressed air piston press ( 0.4 and $0.5 \mathrm{bar}$ for $30 \mathrm{~min}$ ). Then, after $12 \mathrm{~h}$ the cheeses were immersed in brine $(1 \mathrm{~kg}$ of salt per 10 $\mathrm{L}$ water) for $1 \mathrm{~h}$. At that point, they were weighed and a natural color cheese coating was applied (Diplast Ltda., Diplast NA-00, Santiago, Chile). The ripening process was 15 days, at $12^{\circ} \mathrm{C}$ and $80 \%$ relative humidity. A total of 3 production batches were made, with milk standardization at $3 \%$ fat content $(\mathrm{FC})$.

\section{Chanco cheese analysis}

Chanco cheese yield. It was determined as kilograms of cheese obtained per $100 \mathrm{~kg}$ of milk at the beginning and after the ripening period.

Composition of Chanco cheese. Moisture (Method 926.08), protein (Method 990.03), lipid (Method 933.05), ash (Method 923.03) (AOAC, 2005), and sodium (by dry emission spectroscopy) contents as well as kilocalories were determined. All analyses were carried out in triplicate.

\section{Mozzarella sticks development}

Milk from the Normande breed was used in two different processes: Treatment 1 with $25 \%$ brine (P1) and Treatment 2 with a pre-salting at $0.34 \% \mathrm{NaCl}$ per volume of milk (P2), both in triplicate.

Procedure 1. Salty (P1): Milk was standardized to $2.5 \%$ fat, pasteurized $\left(65^{\circ} \mathrm{C}\right.$ for $\left.20 \mathrm{~min}\right)$ and cooled $\left(35 \pm 2^{\circ} \mathrm{C}\right)$. A lactic culture of Streptococcus thermophilus (CHR HANSEN, Streptococcus thermophilus $\mathrm{TH}-4{ }^{\circledR}$, Hoersholm Denmark) was added (0.04 $\left.\mathrm{g} \mathrm{L}^{-1}\right)$ (Jana and Mandal, 2011) to the milk, and then incubated for $15 \mathrm{~min}$ in order to reduce $\mathrm{pH}$ in 0.1 units (Moynihan et al., 2016).
Subsequently, rennet $\left(0.2 \mathrm{~mL} \mathrm{~L}^{-1}\right)$ was added, and the coagulation was carried out during $40 \mathrm{~min}$. The temperature was increased from 37 to $42^{\circ} \mathrm{C}$ at a rate of $0.1^{\circ} \mathrm{C}$ per min for approximately 40 min. Most whey was drained, and $\mathrm{pH}$ reached 5.3-5.6 (Jana and Mandal, 2011). After that, it was kneaded in hot water $\left(0.33 \mathrm{~L}_{\text {water }} \mathrm{L}^{-1}\right.$ milk) at $80-85^{\circ} \mathrm{C}$ for $2-3 \mathrm{~min}$ (Jana and Mandal, 2011; Liu et al., 2015), obtaining the elastic texture of mozzarella cheese. The mozzarella sticks were formed when the curd reached $54-66^{\circ} \mathrm{C}$ (Liu et al., 2015; Moynihan et al., 2016). Then, the sticks were immersed in a $25 \% \mathrm{NaCl}$ brine at $10^{\circ} \mathrm{C}$ for 135 min (Moynihan et al., 2016). Finally, the sticks were vacuum-packed and refrigerated at $4^{\circ} \mathrm{C}$.

Procedure 2. Pre-salting (P2): Milk was standardized to $2.5 \%$ fat. The procedure explained above was followed until whey drainage. Then, a pre-salted solution of whey, containing $0.34 \% \mathrm{NaCl}$ per volume of milk, was prepared and allowed to stand for $7 \mathrm{~min}$. After that, the kneading and molding steps were carried out as explained above. Then, the mozzarella sticks were immersed in water at $10^{\circ} \mathrm{C}$ by $135 \mathrm{~min}$ (Moynihan et al., 2016), vacuum-packed and refrigerated at $4^{\circ} \mathrm{C}$.

Mozzarella cheese yield: It was determined as kilograms of cheese obtained per $100 \mathrm{~kg}$ of milk for both treatments.

\section{Mozzarella sticks analysis}

Color. The coordinates of the CIELab space were determined using a colorimeter (Hunter Lab 45/0 Color Quest, Hunter Associates Laboratory, Inc. Reston, Virginia, USA): $a^{*}$ (greeness-redness), $\quad b^{*}$ (blueness-yellowness) and $L^{*}$ (luminosity $0-100$ ). The chroma value $\left(C^{*}\right)$ was calculated by the equation: $C^{*}=$ $\sqrt{\left(\mathrm{a} *^{2}\right)+\left(\mathrm{b} *^{2}\right)}$, and the color difference respect to the commercial sample by the equation: $\Delta \mathrm{E}=$ $\sqrt{(\Delta L)^{2}+\left(\Delta a^{*}\right)^{2}+\left(\Delta b^{*}\right)^{2}}$ (X-Rite, 2002).

Texture. It was determined on a $7 \times 5 \times$ $1 \mathrm{~cm}$ piece of mozzarella cheese using the universal texturometer (Instron-4467, Instron Corporation, Coronation Road High Wycombe, Buckinghamshire HP123SY, UK) with Kramer cell and piston speed set to $2 \mathrm{~cm} \mathrm{~min}^{-1}$, determining the elasticity and firmness of the product.

Melting capacity. It was determined by the Schreiber test, in which a cheese cylinder (diameter $1.7 \mathrm{~mm}$ and height $2 \mathrm{~cm}$ ) was placed into a Petri dish with a filter paper and heated in an oven at $100^{\circ} \mathrm{C}$ for $1 \mathrm{~h}$. After standing at room temperature for 30 minutes, the maximum diameter of the oil halo in the filter paper was measured. The results were expressed in area (Ma et al., 2011; Zhang et al., 2014). 
Proximal analysis. Moisture (Method 926.08), protein (Method 990.03), lipid (Method 933.05), ash (Method 923.03) (AOAC, 2005) and sodium (by dry emission spectroscopy) contents as well as kilocalories were determined.

All analyses were carried out in triplicate and compared with commercial mozzarella cheese.

Sensory analysis. Three samples of mozzarella cheese were analyzed: with $25 \%$ brine salting process (P1), with a pre-salting process at $0.34 \%$ (P2), and a commercial mozzarella cheese. The samples were conditioned at refrigeration temperature $4^{\circ} \mathrm{C}$. Water and unsalted crackers were available for sample tasting and water to neutralize between samples. An untrained panel consisting of 30 judges evaluated each sample using a 7-point hedonic scale (Anzaldúa-Morales, 1994).

\section{Statistical analysis}

The $\mathrm{t}$-Student for comparison of two samples (Normande and Holstein Friesan breeds) was used for the statistical analysis of milk quality and Chanco cheese parameters with a significance level of 0.05. A randomized complete design was used for the mozzarella assay (P1: 25\% brine immersion; P2: pre-salting at $0.34 \% \mathrm{NaCl}$; Control: commercial mozzarella cheese), and an ANOVA was carried out with a significance level of 0.05 . The Tukey test was used as a comparison test $(P \leq 0.05)$ (Balzarini et al., 2008). In the sensory analysis, a non-parametric analysis of variance, Kruskal-Wallis test, was used with the contrast test proposed by Conover, both with 95\% of confidence (Balzarini et al., 2008). All analyses were performed with the statistical program INFOSTAT version 2008 (Di Rienzo., 2008).

\section{RESULTS AND DISCUSSION}

Milk quality. Fat and protein content was $3.35 \%$ and $2.87 \%$ for the Holstein Friesian, and $3.35 \%$ and $3.16 \%$ for the Normande, respectively (Table 1). Values for HF cow's milk are similar to those reported by Delaby et al. (2009), but only partially agree with those for the Normande as protein content is similar but fat content is lower (3.6\% reference value). The milk from the Normande breed had a higher density ( $\mathrm{P}$ $\leq 0.05$ ), which could be due to a higher protein and lactose content than that of Holstein Friesian. The $\mathrm{pH}$ of milk was within the range required by Chilean regulations (DS № 977/96). If the $\mathrm{pH}$ is lower than the values required by the regulations, coagulation is faster due to the reduction of the charge repulsion between micelles and a higher rennet activity (Lucey et al., 2003).

Chanco cheese yield. The results of the initial cheese yield (IY) and final cheese yield (FY) after 15 days of maturation are shown in Table 2. Cheese yield is mainly affected by fat and casein contents (Chitchyan and Grigoryan, 2016). In the present study, as there were no differences in terms of fat content between breeds, cheese yield was similar $(P>0.05)$ despite of the higher protein content of the Normande milk. According to Wedholm et al. (2006), a higher content of $\kappa$-casein results in a higher cheese yield. However, the content of the different caseins in milk was not determined in the present study. The results show that both breeds have a similar technological performance for the production of Chanco cheese. A mixed herd comprised by Holstein Friesian and Normande breeds would be a viable option for small and medium-sized farmers in order to improve milk

Table 1. Milk quality parameters of the Holstein Friesian and Normande breeds. Tabla 1. Parámetros de calidad de leche en razas Holstein Friesian y Normando.

\begin{tabular}{lccc}
\hline \multirow{2}{*}{ Variable } & \multicolumn{3}{c}{ Average value per breed } \\
\cline { 2 - 4 } & Holstein & Normande & Valor $\mathbf{p}^{*}$ \\
\hline Fat $(\%)$ & 3.35 & 3.35 & 0.9941 \\
Proteins (\%) & 2.87 & 3.16 & 0.0034 \\
Total solids (\%) & 12.00 & 12.44 & 0.2050 \\
Lactose (\%) & 4.58 & 4.74 & 0.0049 \\
Acidity (\%) & 0.14 & 0.14 & 0.2440 \\
Density (g mL & 1026 & 1028 & 0.0164 \\
pH & 6.59 & 6.65 & 0.5680 \\
Urea (g 100 $\left.\mathrm{mL}^{-1}\right)$ & 0.03 & 0.03 & 0.2155 \\
Somatic cells (cell mL $\left.\mathrm{mL}^{-1}\right)$ & 163000 & 111500 & 0.3622 \\
\hline
\end{tabular}

* Comparison by t-Student for two samples with a significance level of 0.05. 
Table 2. Chanco cheese yield (\%) and composition. Tabla 2. Composición y rendimiento de queso Chanco.

\begin{tabular}{lccc}
\hline Variable & \multicolumn{3}{c}{ Standardized milk (3\% FC) } \\
\cline { 2 - 4 } & Holstein average & Normande average & Valor $\mathbf{p}^{*}$ \\
\hline IY (\%) & 15.13 & 14.19 & 0.5695 \\
FY (\%) & 12.13 & 11.13 & 0.5534 \\
Calories (Kcal) & 243.03 & 254.01 & 0.5171 \\
Moisture (\%) & 57.21 & 54.34 & 0.3832 \\
Proteins (\%) & 17.66 & 19.13 & 0.4162 \\
Lipids (\%) & 17.04 & 16.92 & 0.9497 \\
NNE (\%) & 4.78 & 6.31 & 0.4205 \\
Ash (\%) & 3.32 & 3.31 & 0.9490 \\
NaCl (mg 100 g-1) & 975.70 & 1003.71 & 0.7904 \\
\hline
\end{tabular}

FC: Fat content; IY: Initial yield; FY: Final yield; NNE: Non-nitrogenous extract.

* Comparison using t-Student for two samples with a significance level of 0.05 .

quality and allow for high production levels and suitable for production of Chanco cheese.

Composition of Chanco cheese. The composition of Chanco cheese is shown in Table 2. Both cheeses had a moisture content that ranged from 54.34 to $57.21 \%$, being higher than the value stated in the Chilean regulation NCh. 2090 Of. 99 (INN, 1999). This could be due to the ripening period of 15 days, resulting in lower water lost. A longer ripening period of 21 days could cause a higher water loss in this cheese (Arteaga et al., 2009). There were no significant differences in the other parameters of cheese composition ( $\mathrm{P}$ $>0.05)$, which could be attributed to the initial milk composition. Arteaga et al. (2009) reported higher protein and lipid contents $(22.9 \%$ and $27.2 \%$, respectively), and similar water content (54.3\%) in commercial Chanco cheese at 14 days of ripening.

The salt content $(\mathrm{NaCl})$ was between 0.976 and $1.0 \%$. Arteaga et al. (2009) associated alterations in microbial growth, cheese firmness, fermentation, and the presence of unpleasant odor with salt contents that differ with the optimal content of $0.9 \%$. However, those alterations were not observed in this study.

Mozzarella cheese stick yield. The mozzarella cheese yield was 11.60 and $12.21 \%$, for procedure 1 (Salted) and 2 (Pre-salted), respectively, without significant differences $(\mathrm{P}>0.05)$. This can be attributed to the brine stage, which was done for a short time of 135 minutes. The brining stage could last up to 2 days, causing a greater salt absorption and moisture loss. During the salting process, the cheese can lose between 2 and $4.5 \%$ of its weight, which affects yield (Keating y Gaona, 1999).
Sensory analysis of mozzarella cheese sticks. In the sensory analysis (Table 3), flavor scores show significant differences between treatments P1 and P2 and commercial mozzarella cheese (P $\leq 0.05$ ). According to the judges' observations, the difference was the salty taste in P2 "tasteless" and the control had "a plastic taste". Guinee and Fox (2004) suggested that the use of $0.8 \% \mathrm{w} / \mathrm{w} \mathrm{NaCl}$ is probably enough to overcome a low taste. Regarding texture, the control showed significant differences with respect to $\mathrm{P} 1$ and $\mathrm{P} 2$, since the judges indicated that the control was "hard" ( $\mathrm{P} \leq$ 0.05). The commercial mozzarella cheese (control) and the P1 (salted) had greater acceptability and did not differ in general appearance. Mozzarella P1 cheese sticks (salted) was the treatment with the best results regarding the acceptance of the judges; as the percentage of moisture reached by the sticks provided a smooth but consistent texture with a higher punctuation. The percentage of salt highlighted the taste of the mozzarella sticks, contributing to enhance acceptability. In addition, P1 had the best melting capacity.

Composition of mozzarella cheese sticks. Significant differences were found in moisture, ash and sodium contents between P1 and P2 (P $\leq 0.05$ ) (Table 4). According to Jana and Manchal (2011), moisture content should not exceed $50 \%$. A high concentration of salt increases the osmotic pressure, releasing a significant amount of water from the casein network, decreasing the moisture in the cheese (Pinho et al., 2004). In this sense, the significant differences in moisture content observed between the treatments can be explained by the amount of salt added $(0.34 \%$ $\mathrm{NaCl}$ weight/volume of milk to the pre-salting (P2) and 25\% brine (P1) for the immersion of 
the sticks). However, salt addition did not affect protein or lipid content (Zhang et al., 2014).

Color and texture of mozzarella cheese sticks. P1 and P2 treatments had a higher luminosity $\left(\mathrm{L}^{*}\right)$ than the commercial mozzarella cheese (Table 4). The decrease in moisture, and consequently, in the concentration of solids caused the reduction of $L^{*}$. No significant differences were found between treatments P1 and P2 in the parameter $\mathrm{a}^{*}$ (greeness-redness), but both treatments had significant differences with respect to the commercial cheese $(\mathrm{P} \leq 0.05)$, probably because the latter included dyes. The parameters $b^{*}$ (blueness-yellowness) and $C^{*}$ (chroma) were significantly higher in the commercial cheese $(\mathrm{P} \leq$

Table 3. Panel responses of judges in sensory evaluation of mozzarella cheeses from brining (P1), pre-salting (P2), and commercial (Control) procedures.

Tabla 3. Respuestas de panel de jueces en evaluación sensorial de quesos mozzarella de procedimientos de salado (P1), pre-salado (P2) y comercial (Control).

\begin{tabular}{|c|c|c|c|}
\hline \multirow[t]{2}{*}{ Variables } & \multicolumn{3}{|c|}{ Average value for treatments $*$} \\
\hline & Control & Brine (P1) & Pre-salted (P2) \\
\hline Odor & $5 \mathrm{a}$ & $6 a$ & $6 a$ \\
\hline Flavor & $5 a$ & $6 \mathrm{~b}$ & $3 c$ \\
\hline Texture & $5 a$ & $6 \mathrm{~b}$ & $4 \mathrm{~b}$ \\
\hline General aspect & $5 a$ & $6 a$ & $4 \mathrm{~b}$ \\
\hline
\end{tabular}

* Comparison of medians through Kruskal-Wallis test $(\mathrm{P}>0.05)$. Medians with a common letter are not significantly different $(\mathrm{P}>0.05)$.

Table 4. Physicochemical characteristics of mozzarella cheese sticks from brine and pre salted procedure.

Tabla 4. Características fisicoquímicas de varitas de queso mozzarella de procesos de salado y pre salado.

\begin{tabular}{|c|c|c|c|}
\hline \multirow[t]{2}{*}{ Parameters } & \multicolumn{3}{|c|}{ Average value for treatments * } \\
\hline & Commercial & Brine (P1) & Pre salted (P2) \\
\hline \multicolumn{4}{|l|}{ Nutritional composition } \\
\hline Moisture (\%) & - & $51.70 \mathrm{a}$ & $54.68 \mathrm{~b}$ \\
\hline Proteins (\%) & - & $23.89 \mathrm{a}$ & $22.80 \mathrm{a}$ \\
\hline Lipids (\%) & - & $17.53 \mathrm{a}$ & $17.85 \mathrm{a}$ \\
\hline Non-Nitrogenated Extract (\%) & - & $3.70 \mathrm{a}$ & $2.96 \mathrm{a}$ \\
\hline Ashes $(\%)$ & - & $3.13 \mathrm{a}$ & $1.71 \mathrm{~b}$ \\
\hline Calories (kcal) & - & $268.13 \mathrm{a}$ & $263.75 \mathrm{a}$ \\
\hline Sodium (mg/100g) & - & $312.60 \mathrm{~b}$ & $44.99 \mathrm{a}$ \\
\hline \multicolumn{4}{|l|}{ Color $^{1}$} \\
\hline $\mathrm{L}^{*}$ & 80.02 a & $85.73 \mathrm{~b}$ & $89.89 \mathrm{c}$ \\
\hline$a^{*}$ & 0.57 a & $1.88 \mathrm{~b}$ & $1.95 \mathrm{~b}$ \\
\hline$b^{*}$ & 31.68 a & $27.07 \mathrm{~b}$ & $24.05 \mathrm{c}$ \\
\hline$C^{*}$ & 31.68 a & $27.17 \mathrm{~b}$ & $24.15 \mathrm{c}$ \\
\hline$\Delta \mathrm{E}$ & - & 7.39 & 12.49 \\
\hline \multicolumn{4}{|l|}{ Texture } \\
\hline Firmness $\left(\mathrm{N} \mathrm{mm}^{-1}\right)$ & $381.99 \mathrm{~b}$ & $389.05 \mathrm{~b}$ & $273.66 \mathrm{a}$ \\
\hline Elasticity $\left(\mathrm{N} \mathrm{mm}^{-1}\right)$ & $33.86 \mathrm{a}$ & $36.08 \mathrm{a}$ & $25.08 \mathrm{a}$ \\
\hline \multicolumn{4}{|l|}{ Melting capacity } \\
\hline Area $\left(\mathrm{mm}^{2}\right)$ & $4.04 \mathrm{a}$ & $9.26 \mathrm{~b}$ & $3.06 \mathrm{a}$ \\
\hline
\end{tabular}

${ }^{1}$ Color parameters: $\mathrm{a}^{*}$ (green-red), $\mathrm{b}^{*}$ (blue-yellow) and $\mathrm{L}^{*}$ (luminosity 0-100), chroma $\left.\left(\mathrm{c}^{*}\right) \mathrm{C}^{*}=\sqrt{\left(\mathrm{a} *^{2}\right)+\left(\mathrm{b} *^{2}\right.}\right)$, and color difference $(\Delta \mathrm{E}) \Delta \mathrm{E}=\sqrt{(\Delta L)^{2}+\left(\Delta a^{*}\right)^{2}+\left(\Delta b^{*}\right)^{2}}$.

${ }^{*}$ Comparison of treatments through Tukey Test with a significance level of 0.05 . 
0.05), indicating a more intense yellow color, and a greater saturation of the color, caused by the use of dyes in cheese making. This explains the high values of the color difference $(\Delta \mathrm{E})$ between the samples and the commercial cheese. In terms of texture parameters, only firmness presented differences between the treatments. The presalting treatment (P2), resulted in sticks with less firmness and greater moisture than those of the brining treatment (P1) and the commercial mozzarella cheese (control) $(\mathrm{P} \leq 0.05)$. This could be due to salt absorption from the curd that causes turgidity and greater water absorption (Keating y Gaona, 1999; Ramirez-Navas et al., 2017). Moreover, the addition of salt up to $1.4 \%$ $(\mathrm{w} / \mathrm{w})$ would improve protein hydration and the ability of the protein matrix to bind water (Guinee, 2004a). However, salt addition in high concentrations would decrease the proteolytic activity of the enzymes, increasing water loss from the protein network, resulting in lower moisture and, in turn, an increase in firmness of the cheese (Zhang et al., 2014). This agrees with Liu et al. (2015), who have indicated that the higher the moisture content in cheese, the lower the firmness. The melting capacity of mozzarella cheese in P1 was greater than that in the control and $\mathrm{P} 2(\mathrm{P} \leq 0.05)$. The increase in cheese melting capacity by increasing the salt content can be attributed to the release of calcium salts from the cheese, from the monocalcic paracaseinate and the formation of paracasein.

\section{CONCLUSIONS}

Milk from the Normande and Holstein Friesian breeds has different protein and lactose content but similar technological performance for the production of Chanco cheese. It is possible to produce mozzarella cheese sticks using milk from Normande cows and to recommend this dual-purpose breed for the Nuble Region, Chile.

\section{ACKNOWLEDGMENT}

This study was funded by the Corporación de Fomento de la Producción (CORFO), Innova Biobío 14.60-IN.IIP.

\section{LITERATURE CITED}

Aguilera, P. 2016. El queso de Chanco: un producto típico de la industria popular de Chile (siglos XVIII y XIX). RIVAR 3(8):41-63.

Anzaldúa-Morales, A. 1994. The sensory evaluation of food in theory and in practice. Editorial Acribia, Zaragoza, Spain.
AOAC. 2005. Official methods of analysis of AOAC International. 18th. ed. AOAC International, Gaithersburg, USA.

Arteaga M., L.H. Molina, M. Pinto, y C. Brito. 2009. Caracterización de queso Chanco enriquecido con suero lácteo en polvo. Rev. Chil. Nutr. 36(1):53-62.

Barría, N. y G. Stolzenbach. 1992. Comparación de la raza Frisón Negro con la cruza Holstein $x$ Frisón Negro para la producción de leche y carne en la X Región (Chile). Av. Prod. Anim. 17(1-2):93-102.

Brito, C., X. Manríquez, L.H. Molina, y M. Pinto. 2003. Estudio de maduración de queso Chanco bajo en grasa elaborado con leche homogeneizada. Arch. Latinoam. Nutr. 53(3):299-305.

Chitchyan, Z.T., and A.A. Grigoryan. 2016. Yield and quality of brine-ripened cheeses, production from the milk of Jersey and Simmental cows. Ann. Agr. Sci. 14(1):64-66.

Delaby, L., P. Faverdin, G. Michel, C.Disenhaus, and J.L. Peyraund. 2009. Effect of different feeding strategies on lactation performance of Holstein and Normande dairy cows. Animal 3(6):891-905.

Dillon, P., Buckley, P. O'Connor, D. Hegarty, and M. Rath. 2003a. Comparison of different dairy cow breeds on a seasonal grass-based system of milk production 1. Milk production, live weight, body condition score and DM intake. Livest. Prod. Sci. 83(1):21-33.

Dillon, P., S. Snijders, F. Buckley, B. Harris, P. O'Connor, and J.F. Mee. 2003b. Comparison of different dairy cow breeds on a seasonal grass-based system of milk production 2 . Reproduction and survival. Livest. Prod. Sci. 83(1):35-42.

Guinee, T.P. 2004. Salting and the role of salt in cheese. International Journal of Dairy Technology 57(2-3):99-109.

Guinee, T.P. and P.F. Fox. 2004. Salt in cheese: physical, chemical and biological aspects. p. 207-259. In P.F. Fox, P.L.H. McSweeney, T.M. Cogan and T.P. Guinee (eds.). Cheese: chemistry, physics and microbiology. Volume 1. General Aspects. 3rd. ed. Academic Press, London, UK.

Heins, B.J., L.B. Hansen, and A.J. Seykora. 2006a. Fertility and survival of pure Holsteins versus crossbreds of Holsteins with Normande, Montbeliarde, and Scandinavian Red. J. Dairy Sci. 89(12):4944-4951.

Heins, B.J., L.B. Hansen, and A.J. Seykora. 2006b. Calving difficulty and stillbirths of pure Holsteins versus crossbreds of Holstein with Normande, Montbeliarde, and Scandinavian Red. J. Dairy Sci. 89:2805-2810. 
Hussain, I., A.E. Bell, and A.S. Grandison. 2011. Comparison of the rheology of mozzarellatype curd made from Buffalo and cows' milk. Food Chem. 128:500-504.

INN. 1979a. Leche y productos lácteos. Determinación del pH. NCh 1671 Of. 79. Instituto Nacional de Normalización (INN), Santiago, Chile.

INN. 1979b. Leche. Determinación de densidad. NCh 1672: Of. 79. Instituto Nacional de Normalización (INN), Santiago, Chile.

INN. 1979c. Leche. Determinación del contenido de materia grasa. Método de Gerber. Norma Chilena 1016/1: OF. 79. Instituto Nacional de Normalización (INN), Santiago, Chile.

INN. 1998. Determinación de la de acidez titulable. NCh 1738: Of. 98. Instituto Nacional de Normalización (INN), Santiago, Chile.

INN. 1999. Productos Lácteos. Queso Chanco. Requisitos. NCh 2090. Instituto Nacional de Normalización (INN), Santiago, Chile.

ISO. 2013. Milk and liquid milk products. Guidelines for the application of midinfrared spectrometry [on line]. International Organization for Standardization (ISO) 9622:2013. Available at <https://www.iso. org/obp/ui/\#iso:std:iso:9622:ed-2:v1:en> [Accessed 09 September 2019].

Jana, A.H., and P.K. Mandal. 2011. Manufacturing and quality of mozzarella cheese: a review. Int. J. Dairy Sci. 6(4):199-226.

Katz, G., U. Merin, D. Bezman, S. Lavie, L. Lemberskiy-Kuzin, and G. Leitner. 2016. Real-time evaluation of individual cow milk for higher cheese-milk quality with increased cheese yield. J. Dairy Sci. 99:4178-4187.

Keating, P.F., y H. Gaona. 1999. Introducción a la lactología. 2a. ed. Limusa, D.F, México.

Lacoste, P., D. Jiménez, and N. Soto. 2014. Genesis and identity of Chanco cheese (Chile 1750-1860). A contribution to studies on Appellations of Origin in Latin America. Cien. Inv. Agr. 41(3):317-325.

Liu, H.Y., W.Z. Zhu, B.Y. Lu, Z.H. Wei, and D.X. Ren. 2015. Effect of feed selenium supplementation on milk selenium distribution and mozzarella quality. J. Dairy Sci. 98(12):8359-8367.

Lucey, J.A., M.E. Johnson, and D.S. Horne. 2003. Invited review: Perspectives on the basis of the rheology and texture properties of cheese. J. Dairy Sci. 98(9):2725-2743.
Ma, X., B. James, L. Zhang, and E. EmanuelssonPatterson. 2011. Correlating mozzarella cheese properties to production processes by rheological, mechanical and microstructure study: meltability study and activation energy. Procedia Food Science 1:536- 544.

Moynihan, A.C., S. Govindasamy-Lucey, M. Molitor, J.J. Jaeggi, M.E. Johnson, P.L.H. McSweeney, et al. 2016. Effect of standardizing the lactose content of cheesemilk on the properties of lowmoisture, part-skim mozzarella cheese. J. Dairy Sci. 99(10):7791-7802.

ODEPA. 2019. Lechey Derivados [enlínea]. Oficina de Estudios y Políticas Agrarias (ODEPA), Ministerio de Agricultura. Gobierno de Chile. Disponible en <https://www.odepa. gob.cl/rubros/leche-y-derivados> [Consulta: 09 septiembre 2019].

Pinho, O., E. Mendes, M.M. Alves, and I.M.P.L.V.O. Ferreira. 2004. Chemical, physical, and sensorial characteristics of "Terrincho" ewe cheese: changes during ripening and intravarietal comparison. J. Dairy Sci. 87(2):249-257.

Ramírez-Navas, J.S., J. Aguirre-Londoño, V.A. Aristizabal-Ferreira, y Castro-Narváez, S. 2017. La sal en el queso: diversas interacciones. Agronomía Mesoamericana 28(1):303-316. https://dx.doi.org/10.15517/ am.v28i1.21909

Tornadijo, M.E., A. I. Marra, M.C. García Fontán , B. Prieto, y J. Carballo. 1998. La calidad de la leche destinada a la fabricación de queso: calidad química. Milk quality for cheese production: chemical quality a calidade da leite destinada á fabricación de queixo: calidade química. CYTA - Journal of Food 2(2):79-91.

Wedholm, A., L.B. Larsen, H. Lindmark-Månsson, A.H. Karlsson, and A. Andrén. 2006. Effect of protein composition on the cheese-making properties of milk from individual dairy cows. J. Dairy Sci. 89:3296-3305.

X-Rite. 2002. Guía para entender la comunicación del color [en línea]. X-Rite, USA. Disponible en $\quad<\mathrm{http}: / /$ www.mcolorcontrol.com/ archivos/L10-001_Understand_Color es.pdf>. [Consulta: 12 noviembre 2016].

Zhang, J.Q., L. Hao, B. Chun, C. Rong-an, and Z. Li-ping. 2014. Effect of sodium chloride on meltability of mozzarella cheese. J. North. Agric. Univ. 21(3):68-75. 